\title{
Importance of Surveillance Studies on Tularemia in Thrace Region of Turkey
}

\author{
Şaban Gürcan (1) \\ Department of Medical Microbiology, Trakya University School of Medicine, Edirne, Turkey
}

To the Editor,

Francisella tularensis was first isolated in 1912 by McCoy and Chapin. It was included in a new genus named Francisella in 1947 in honor of Edward Francis and its name was changed to F. tularensis. ${ }^{1,2} F$. tularensis has been included in biological weapon programs due to its characteristics such as low infective dose, high virulence, and high mortality rate. ${ }^{1,3}$ Tularemia was first diagnosed in 1936 in Turkey and intensive research was done related to this new disease and the agent. ${ }^{4}$

F. tularensis is a highly virulent bacterium and the sensitivity of the culture is very low, such as $25 \%$ in clinical samples. ${ }^{5,6}$ The culture is mostly used for the diagnosis of the disease caused by F. tularensis subsp. holarctica with lower virulent subspecies in Scandinavian countries. ${ }^{7}$ Molecular tests are rapid diagnostic tests but expensive. For these reasons, the diagnosis of tularemia is usually made by serological tests. Serological tests are the most preferred tests in diagnosis because they are faster, more sensitive, cheaper, and easier compared to cultures. ${ }^{5,8}$

\section{Tularemia Studies in the European Part of Turkey (Thrace Region)}

Tularemia outbreak in the Thrace region has been reported in 1936 in the Kirklareli and Tekirdağ provinces. The common characteristics of these cases are that they reside in villages along the Kaynarca stream on the Kirklareli-Tekirdağ line. In the same region, no other case was reported for 60 years after the second epidemic occurred in 1945 in a district of Kirklareli on the route of the Kaynarca stream. ${ }^{8}$ The fact that the disease has not been reported in humans in this long period may be due to the following reasons:

i) Cessation of the agent's existence in nature;

ii) Preventing the agent's transmission to people;

iii) Lack of disease notification, and

iv) Misdiagnosis of the disease with other diseases such as tuberculous lymphadenitis, which may have led to the lack of case reports.
The misdiagnosis of the disease with other diseases such as tuberculous lymphadenitis has been shown in recent studies. In 67 provinces of Turkey, 1170 patients were diagnosed with tuberculosis cervical lymphadenitis (TCL) between the years of 2008 and 2011. Antibodies against $F$. tularensis was determined in the serological tests of $96(8.2 \%)$ patients. ${ }^{9}$ In a later study, when polymerase chain reaction (PCR) tests were performed for $F$. tularensis in paraffin tissue blocks of 32 patients diagnosed with TCL in Bursa, Turkey, conflicting diagnosis between tuberculosis and tularemia was confirmed in 6 patients $(19 \%))^{10}$

A seroprevalence study was conducted in 2006 to clarify that no tularemia cases have been reported in 60 years in the Thrace region. ${ }^{8}$ In this study, serological research was conducted on 1782 volunteers by randomly selecting 30 villages from each of the 3 cities of the region ( 90 villages in total). F. tularensis antibodies investigated by the tularemia microagglutination test were found to be positive in 5 adult males $(0.3 \%)$ at titers varying between $1 / 20$ and $1 / 160$. Interestingly, it was found that 2 of the 5 seropositive people resided in one of the villages of Kirklareli (Ceylanköy), which was affected by the epidemic in 1936. Another seropositive case was determined to be in another village of Kirklareli, while the others were in the villages of the Tekirdag and Edirne provinces. ${ }^{8}$ These findings can suggest that the 60 -year silence in the Thrace region may be due not to the absence of tularemia cases but to the misdiagnoses of the cases. Actually, it was confirmed on the basis of the detection of the tularemia outbreak in the villages of Edirne and Tekirdağ, two other cities in the Thrace region in 2005 and $2010 .^{11,12}$

The seroprevalence study in the Thrace region and the occurrence of the tularemia epidemic in 2005 and 2010 required the investigation of the reservoirs of the agent in nature. ${ }^{8,11}$ Since the water sources that are thought to be contaminated by rodents were always suspected as a source in previous outbreaks, it was planned to investigate the presence of $F$. tularensis in rodent specimens via bacterial culture as well as serological, and molecular

\footnotetext{
Address for Correspondence: Şaban Gürcan, Department of Medical Microbiology, Trakya University School of Medicine, Edirne, Turkey e-mail: sabangurcan@trakya.edu.tr

Received: December 31, 2020 Accepted: February 3, 2021 •DOI: 10.5152/balkanmedj.2021.20201

Available at www.balkanmedicaljournal.org

ORCID iD of the author: Ş.G. 0000-0002-5052-481X.

Cite this article as:

Gürcan Ş. Importance of surveillance studies on tularemia in thrace region of Turkey. Balkan Med J. 2021; 38(3):198-200.

Copyright@Author(s) - Available online at http://balkanmedicaljournal.org/
} 
methods. Rodents living on the banks of the streams and houses were caught in the villages of Kirklareli, Tekirdağ, and Edirne in the Thrace region, where the tularemia epidemic was previously reported..$^{13} F$. tularensis could not be isolated in cultures made from liver and spleen tissues of mice, and IgG positivity in rodent serum with Microagglutination test (MAT) test was not detected in serological tests. However, PCR positivity has been identified in the spleen tissue of 2 mice caught near the stream in Kaynarca where the first tularemia cases were seen in Turkey and located in the birthplace of the Kaynarca stream. This finding can be evaluated as the causative agent found endemically in the region in tularemia reservoirs and explains the reason for seropositivity detected in 2 people in Ceylanköy, near the Kaynarca stream, in the seroprevalence study conducted in $2006 .{ }^{13}$ It can be suggested that mice carrying the agent have been in this region for years and may occasionally cause illness in people who come into contact with stream water.

Seropositivity in seroprevalence studies in humans in the Thrace region and the detection of positivity in molecular tests in mice with reservoir roles in tularemia have led to further studies. Studies have been continued to clarify whether there is a change in seropositivity in humans in the past 10 years and contamination in the water that people contact and drink. ${ }^{14} F$. tularensis DNA was detected by PCR tests in 2 streams and 3 main water sources, although the causative agent could not be isolated in the cultures in the water samples taken from Kirklareli streams and main water sources. Streams with PCR positivity are those passing through Celaliye and Kavaklı towns. The main water sources with PCR positivity are in the villages of Hamzabey, Ceylanköy, and Tatarköy around the Kaynarca stream. The Ceylanköy village of Kirklareli attracted attention as the most risky village in Thrace due to i) the detection of 2 seropositive cases in 2006 ,

ii) localization in the streamline where the agent was positive by PCR in 2012, and

iii) PCR positivity was detected in the main water sources of the village in 2016 .

In a study conducted in 2016, after the detection of PCR positivity in main water sources, chlorination of water was quickly achieved in cooperation with health authorities in order to prevent a new epidemic. ${ }^{14}$ After the chlorination process of the water, molecular analysis was repeated and no tularemia PCR positivity was detected. As a result of informing the health institutions and following up the process, no new cases were reported. The possibility of an outbreak was recognized very early due to tularemia surveillance. Thus, it was possible to prevent the epidemic before the outbreak started. In previously reported tularemia outbreaks in Turkey, the outbreak reservoirs have been investigated following the outbreak and measures were taken to limit the epidemic., ${ }^{415}$ However, Uğur et al.'s research ${ }^{14}$ is very valuable in terms of showing that performing surveillance studies in risky regions can prevent tularemia outbreaks by early recognition of risks and taking timely measures (Figure 1).

\section{Seroprevalence Investigations in the World and Turkey} When seroprevalence studies in the world are examined, it is seen that they are carried out for 2 purposes:

i) To determine the number of people affected by the epidemic in areas where there are tularemia outbreaks at that time and to determine the size of the epidemic.

ii) To determine the number and rate of those who encounter the agent in the general population when there is no epidemic.

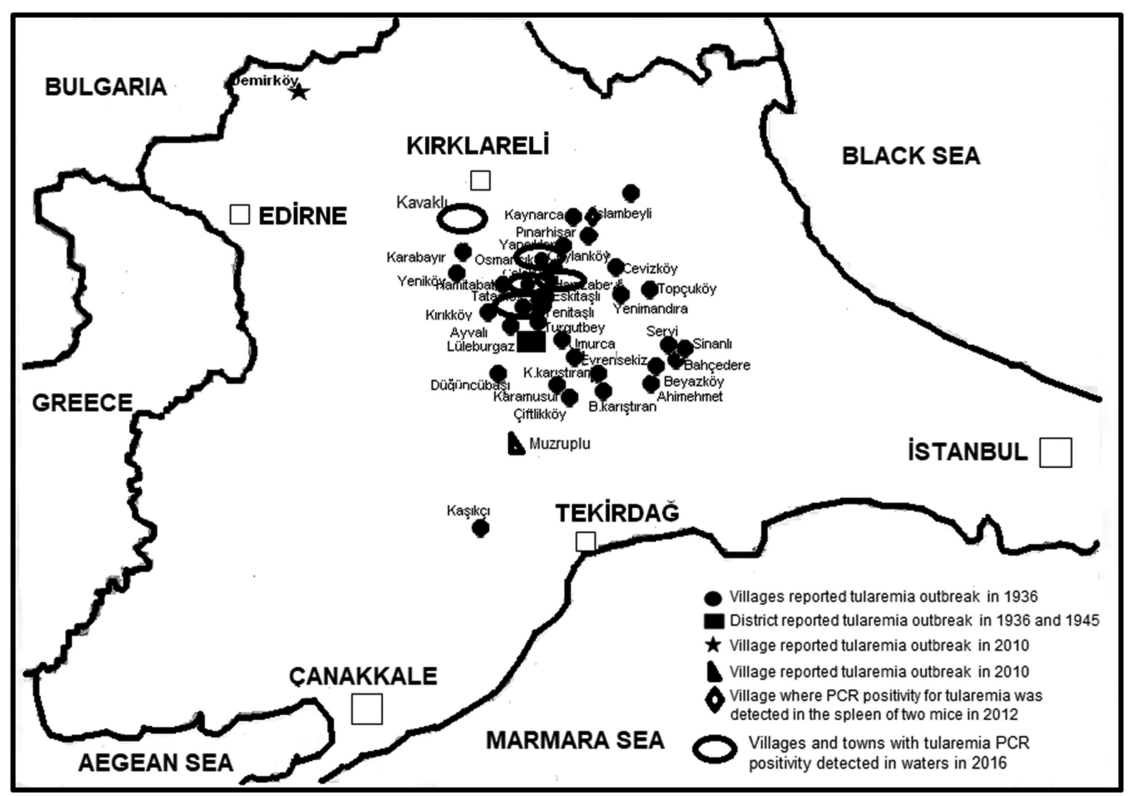

FIG. 1. Tularemia researches in Thrace Region between 1936 and 2016. 
In seroprevalence studies conducted in epidemic regions in Europe, the presence of tularemia antibodies at a rate of 9.7-19.7\% was determined. ${ }^{16}$ The seropositivity rates in areas with outbreaks in Turkey are $2.6-31.3 \% .^{11,15,17,18}$ Of 240 farmers and animal husbandry in Turkey, 71 volunteers $(29.6 \%)$ have tularemia seropositivity In Erzurum, Turkey. ${ }^{19}$ It was determined that tularemia seropositivity in the general population was $0-1.8 \%$ when there was no epidemic in North America and Sweden. ${ }^{16}$ In Spain, seropositivity of tularemia was reported at a rate of $0.19 \%$ in the general population in sera taken from 4825 people in $1997 .{ }^{20}$ In fact, 507 confirmed cases of tularemia were detected at the same site 10 years later. ${ }^{21,22}$ In Turkey, there is only one study investigating tularemia seropositivity in the general population in the absence of an epidemic. In this study, tularemia seropositivity was found in 5 $(0.03 \%)$ of 1782 volunteers. ${ }^{8}$

Serological test is the most appropriate test for both diagnosis and for detecting past encounters with agents of tularemia. ${ }^{5}$ The detection of seropositivity in tularemia seroprevalence studies should be considered as a warning for the risk of tularemia epidemic in that area, used to determine where the agent is present in that region, and adopted to confirm if it affects people during that time and in the following periods. Surveillance and serological studies in people and regions at risk for tularemia can be useful in taking precautions and determining health policies. It is a good starting point for planning other research on tularemia and directing resources and the workforce correctly.

Conflict of Interest: The author has no conflicts of interest to declare.

Funding: The author declared that this study had received no financial support.

\section{REFERENCES}

1. Ellis J, Oyston PCF, Green M, Titball RW. Tularemia. Clin Microbiol Rev. 2002;15(4):631-646. [CrossRef]

2. Dennis DT, Inglesby TV, Henderson DA, et al. Tularemia as a biological weaponmedical and public health management. J Am Med Assoc. 2001;285(21):2763-2773. [CrossRef]

3. Shapiro DS, Schwartz DR. Exposure of laboratory workers to Francisella tularensis despite a bioterrorism procedure. J Clin Microbiol. 2002;40(6):2278-2281. [CrossRef]
4. Gürcan S. Epidemiology of tularemia. Balk Med J. 2014;31(1):3-10. [CrossRef]

5. Gürcan S. Francisella tularensis and tularemia in Turkey. Mikrobiyol Bul. 2007;41(4):621-636.

6. Gürcan S, Karabay O, Karadenizli A, et al. Characteristics of the Turkish isolates of Francisella tularensis. Jpn J Infect Dis. 2008;61(3):223-225.

7. Johansson A, Berglund L, Eriksson U, et al. Comparative analysis of PCR versus culture for diagnosis of ulceroglandular tularemia. J Clin Microbiol. 2000;38(1):22-26.

8. Dedeoğlu Kılınç G, Gürcan S, Eskiocak M, Kiliç H, Kunduracilar H. Investigation of tularemia seroprevalence in the rural area of Thrace Region in Turkey. Mikrobiyol Bul. 2007;41(3):411-418.

9. Karabay O, Kilic S, Gurcan S, et al. Cervical lymphadenitis: tuberculosis or tularaemia? Clin Microbiol Infect. 2013;19(2):E113-E117. [CrossRef]

10. Yıldırım S, Turhan V, Karadenizli A, et al. Tuberculosis or tularemia? A molecular study in cervical lymphadenitis. Int J Infect Dis. 2014;18:47-51. [CrossRef]

11. Gürcan S, Eskiocak M, Varol G, et al. Tularemia re-emerging in European part of Turkey after 60 years. Jpn J Infect Dis. 2006;59(6):391-393.

12. Gürcan Ş, Saracoglu GV, Karadenizli A, et al. Tularemia as a result of outdoor activities for children in the countryside. Turk J Med Sci. 2012;42:1044-1049.

13. Ünal Yilmaz G, Gürcan S, Özkan B, Karadenizli A. Investigation of the presence of Francisella tularensis by culture, serology and molecular methods in mice of Thrace Region, Turkey. Mikrobiyol Bul. 2014;48(2):213-222. [CrossRef]

14. Uğur M, Gürcan Ş, Eskiocak M, Karadenizli A. Investigation of tularemia incidence and presence of Francisella tularensis in streams/mains water in a risky region of Thrace. Klimik J. 2019;32(1):78-83.

15. Gürcan S, Otkun MT, Otkun M, Arıkan OK, Özer B. An outbreak of tularemia in western Black Sea region of Turkey. Yonsei Med J. 2004;45(1):17-22. [CrossRef]

16. Feldman KA, Stiles-Enos D, Julian K, et al. Tularemia on Martha's Vineyard: seroprevalence and occupational risk. Emerg Infect Dis. 2003;9(3):350-354. [CrossRef]

17. Gedikoğlu Suna GG, Safiye H. Epidemiologic aspects of tularemia in Bursa. Infeksiyon Derg. 1990;4(7):9-15.

18. Tatman Otkun M, Akcali A, Karadenizli A, et al. epidemiological evaluation of a rapidly-prevented tularemia outbreak in Canakkale Province, Turkey. Mikrobiyol Bul. 2001;45:10.

19. Yazgı H, Uyanık MH, Ertek M, et al. Tularemia seroprevalence in the risky population living in both rural and urban areas of Erzurum. Mikrobiyol Bul. 2011;45(1):6774 .

20. Gutiérrez MP, Bratos MA, Garrote JI, et al. Serologic evidence of human infection by Francisella tularensis in the population of Castilla y Leon (Spain) prior to 1997 FEMS Immunol Med Microbiol. 2003;35(2):165-169. [CrossRef]

21. Martin C, Gallardo MT, Mateos L, et al. Outbreak of tularaemia in Castilla y Leon, Spain. EURO Surveill Bull Eur Mal Transm Eur Commun Dis Bull. 2007;12(45):E071108.1. [CrossRef]

22. Allue M, Sopena CR, Gallardo MT, et al. Tularaemia outbreak in Castilla y Leon, Spain, 2007: an update. EURO Surveill Bull Eur Mal Transm Eur Commun Dis Bull. 2008;13(32):18948. 